\title{
DEVELOPMENT AND RESEARCH CANDIES WITH INCREASED BIOLOGICAL VALUE WITH PROTEIN-FAT COMPOSITE
}

\author{
Sergiy Bochkarev \\ Department of Physical Education \\ National Technical University «Kharkiv Polytechnic Institute» \\ 2 Kyrpychova str., Kharkiv, Ukraine, 61002 \\ bochkarev.s.v@gmail.com \\ Nataliya Cherevichna \\ Department of Commodity and examination of foods \\ Kharkiv State University of Food Technology and Trade \\ 333 Klochkivska str., Kharkiv, Ukraine, 61051 \\ cherevichna@gmail.com \\ Igor Petik \\ Ukrainian Scientific Research Institute of Oils and Fats of \\ the National Academy of Agricultural Sciences of Ukraine \\ 2A Dziuba ave., Kharkiv, Ukraine, 61019 \\ igor171984@gmail.com \\ Anna Belinska \\ Department of Organic Synthesis and Nanotechnology \\ National Technical University «Kharkiv Polytechnic Institute» \\ 2 Kyrpychova str., Kharkiv, Ukraine, 61002 \\ belinskaja.a.p@gmail.com \\ Oleksandra Varankina \\ Department of Biotechnology, Biophysics and Analytical Chemistry \\ National Technical University «Kharkiv Polytechnic Institute» \\ 2 Kyrpychova str., Kharkiv, Ukraine, 61002 \\ avarankina@gmail.com \\ Oleksandra Zakhozhyi \\ Department of Biotechnology, Biophysics and Analytical Chemistry \\ National Technical University «Kharkiv Polytechnic Institute» \\ 2 Kyrpychova str., Kharkiv, Ukraine, 61002 \\ zahozhyy@mail.ru \\ Oleksandra Ilina \\ Department of Biotechnology, Biophysics and Analytical Chemistry \\ National Technical University "Kharkiv Polytechnic Institute» \\ 2 Kyrpychova str., Kharkiv, Ukraine, 61002 \\ sasha.ilina.05.97@gmail.com

\section{Olena Shyrokova} \\ Department of Fat Technologies and Fermentation Products \\ National Technical University «Kharkiv Polytechnic Institute» \\ 2 Kyrpychova str., Kharkiv, Ukraine, 61002 \\ lena.shirokova1234@gmail.com
}

Abstract

The composition of "truffle" cream candies enriched with polyunsaturated fatty acids of $\omega-3$ group, sesamol and tocopherols antioxidants and plant proteins in the digestible form was developed. Cream candies contain a protein-fat composite based on flax, 
sesame and sunflower seeds. These products can be used both in everyday and in special nutrition of athletes, soldiers, heavy manual workers, children and young people. It was determined that the oxidative stability of the model creamy candy mass increased with the concentration of protein-fat composite in it. The positive effect of the plant supplement on taste, aroma and "mouth-feeling" sensation parameters was proved by the obtained profilogram of organoleptic quality control parameters of experimental samples of candy masses with different content of protein-fat composite. Thus, it was established that the protein-fat composite in the composition of sweets improved its organoleptic and physicochemical quality control parameters, and also increased shelf life. The development allows to increase the consumer evaluation of the quality of "truffle" cream candies and, accordingly, their competitiveness.

Keywords: candy mass, protein-fat composite, flax, sesame, sunflower seeds, oxidation, biological value.

\section{Introduction}

Recently, the confectionery industry produces a variety of products for the general public. Sugar confections characterized by a high content of caloric, carbohydrate, fat and low protein content are sufficiently popular [1]. They have a steady demand among consumers, especially children and youth. But usually modern confectionery products, in particular, sugary, have two significant drawbacks - a low shelf life and an unbalanced composition [2]. And, if the first problem can be effectively solved by the use of preservatives and antioxidants in most cases of synthetic origin [3], but the problem of unbalanced fatty acid composition is almost always left unaddressed [4, 5].

It should be noted that in recent years, manufacturers have sought to increase the attractiveness of their products by increasing their biological value [6-8]. Most often this is expressed in the application of semi-finished products from natural raw materials. Indeed, the complexes of vitamins, minerals and antioxidants are contained in their composition. But the number of such confectionery products, reasonably enriched with ingredients for health purposes, is less than $1 \%$ of the total world production [9].

The composition of a protein-fat composite based on crushed seeds of flax, sunflower and sesame was substantiated in [10-12], its antioxidant properties were investigated, and processing parameters ensuring the maximum biological value of the composite were determined.

The aim of the work is the development of Ukrainian competitive confectionery products enriched with such biologically valuable substances as polyunsaturated fatty acids, antioxidants and proteins. These products can be used both in everyday and in special meals for athletes, heavy manual workers and military personnel.

\section{Materials and Methods}

The following materials were used for research:

- sunflower seeds according to DSTU 7011;

- flax seeds according to DSTU 4967;

- sesame seeds according to DSTU 7012;

- cocoa butter according to DSTU 5004;

- cocoa powder according to DSTU 4391;

- sugar powder according to DSTU 4623;

- skimmed milk powder according to DSTU 4273.

The preparation of the protein-fat composite includes the following stages: mixing of the oil seeds, their grinding to $0.2-0.4 \mathrm{~mm}$, moisture-thermal treatment using a microwave source according to [12]. This protein-fat composite has a high content of irreplaceable branched amino acids - leucine, isoleucine, valine, and also minimal content of tryptophan. With regard to its fatty acid composition, the ratio of essential polyunsaturated fatty acids (PUFA) of $\omega-6$ and $\omega-3$ groups is about 1.4:1. This composition is justified for enriching food intended for athletes during physical exertion, military personnel, heavy manual workers in changing climatic conditions and other segments of the population [8].

A cream candy mass as an object of enrichment with a protein-fat composite for the "truffle" type candies production was chosen. The choice is based on the fact that the classic recipe for 
these candies is quite simple, and the ingredient composition is represented by natural products. This candy mass (according to DSTU 4135) is a finely ground sugar and fat base with or without addition of cereals or other crops, food additives and other raw materials, with a fat mass fraction of $18 \%$ at least.

The preparation of cream candy mass includes such stages as formulation components preparation (powdered sugar, cocoa powder, skimmed milk powder, protein-fat composite), their mixing and homogenizing, candy mass spreading (melted cocoa butter adding), candy mass warming up (mixing after spreading to transfer the mass to a plastic state), candy mass tempering (heating to $38 \pm 1{ }^{\circ} \mathrm{C}$ with following cooling to $28 \pm 1{ }^{\circ} \mathrm{C}$ for the required polymorphic cocoa butter form forming), candy mass churning and its shaping.

Oxidative stability of candy masses is determined by the accelerated method of "active oxygen". The method is based on the oxidation of candy masses at a temperature of $85 \pm 2{ }^{\circ} \mathrm{C}$ in a reactor with free light and air access and with mixing. The dependence of changing of the oil peroxide value from the time is built by measuring the time in hours and the peroxide value in $1 / 2 \mathrm{O}$ mmol per $\mathrm{kg}$. And then the induction period can be graphically determined using this dependence. The induction period of the samples oxidation is the time indicating to the significant increasing of oxidation products concentration. An antioxidant activity is the total oxidation inhibition effect caused by a combination of elementary initiation reactions, lengthening and chains termination.

Sensory evaluation is carried out by testers according to ISO 8586-1 and ISO 8586-2. The olfactory, taste and tactile sensitivity of experts is determined according to ISO 5496, ISO 3972 and ISO 11036. The special score system quantitatively expressing a number of quality control parameters of candy samples is used for the sensory evaluation.

The organoleptic evaluation of candy masses is determined according to GOST 5897. The moisture mass fraction in candy masses is determined according to GOST 5900, the fat mass fraction - according to GOST 5899, the total sugar mass fraction - according to GOST 5903.

Mathematical methods with Microsoft Excel 2016 and Statistica Advanced 8 software packages are used for experiment planning and data processing (plotting diagrams, graphs, and regression and variance analysis).

\section{Experimental procedures}

The model candy mass was obtained in the laboratory conditions according to the formulation presented in Table 1. It should be noted that the rate of crystallization of the fat phase allows the filling not to freeze during the deposition and crystallize after the formation of the body.

Table 1

Model creamy mass formulation

\begin{tabular}{cccc}
\hline Name of raw materials & Quantity of dry substances (DS), $\%$ & \multicolumn{2}{c}{ Quantity of raw materials, kg } \\
in DS
\end{tabular}

The oxidation induction periods of the investigated candy mass samples without and with the protein-fat composite addition in an amount of 5,10 and $20 \%$ at a temperature of $85 \pm 2{ }^{\circ} \mathrm{C}$ are shown in Fig. 1. 


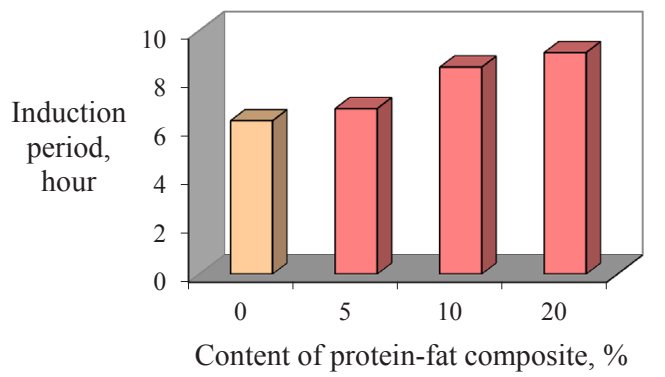

Fig. 1. The oxidation induction periods of investigated creamy candy masses at a temperature of $85 \pm 2{ }^{\circ} \mathrm{C}$

The sensory evaluation of the experimental candy samples was carried out for determining the effect of the protein-fat composite on the consumer properties of cream candies. The form, consistency, sweetness, color, taste and aroma of candy samples were assessed during the sensory evaluation. The results of the sensory evaluation are reflected in the profilogram, which is shown in Fig. 2.

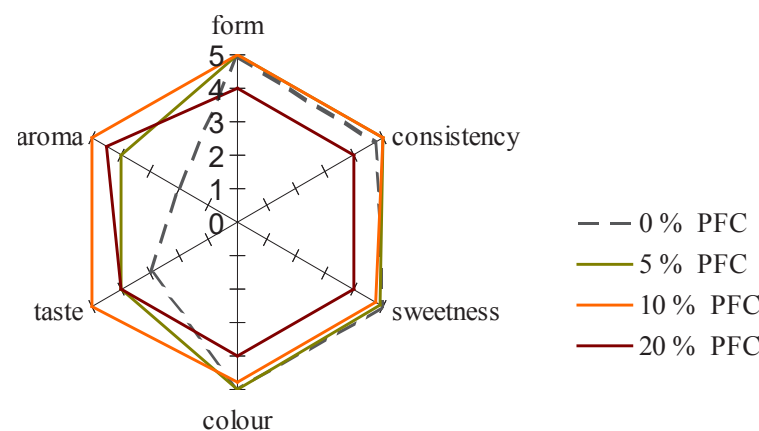

Fig. 2. Profilogram of organoleptic quality control parameters of candy masses samples with different content of protein-fat composite (PFC)

The study of physicochemical quality control parameters of candy mass with a justified content of protein-fat composite was the next stage of the work. The results of this study are presented in Table 2.

Table 2

Physicochemical quality control parameters of candy masses

\begin{tabular}{cccc}
\hline $\begin{array}{c}\text { Physicochemical } \\
\text { quality control parameters }\end{array}$ & $\begin{array}{c}\text { Control sample } \\
(\mathbf{0} \% \mathbf{P F C})\end{array}$ & $\begin{array}{c}\text { Sample } \\
\text { with 10 \% PFC }\end{array}$ & $\begin{array}{c}\text { The norm according } \\
\text { to DSTU 4135 }\end{array}$ \\
\hline $\begin{array}{c}\text { Moisture mass fraction, \% } \\
\text { Fat mass fraction, \% }\end{array}$ & 2,31 & 3,40 & not more than $7 \%$ \\
$\begin{array}{c}\text { Total sugar mass fraction } \\
\text { in terms of sucrose, \% }\end{array}$ & 34,06 & 35,15 & not less than $27 \%$ \\
& 47,30 & 42,54 & not standardized
\end{tabular}

The model candy mass with the composition presented in Table $\mathbf{1}$ was used as a control sample.

\section{Discussion}

The oxidative stability of the model cream candy mass with the addition of a different amount of the protein-fat composite, which was described in [10], in comparison with the control sample (the model candy mass) was investigated. 
It can be seen in Fig. 1 that the stability to oxidation, and, consequently, the predicted storage times of the investigated creamy candy masses depend on the content of the protein-fat composite in them. The induction period of candy mass with $5 \%$ protein-fat composite exceeds that of the control sample by only $8 \%$, but the induction periods of candy masses containing $10 \%$ and $20 \%$ of the additive exceed the benchmark by $35 \%$ and $44 \%$, respectively.

From the profilogram of the organoleptic quality control parameters of the experimental samples of candy masses with different contents of the protein-fat composite (Fig. 2), it is evident that the use of the protein-fat composite in the cream candy masses affects on such organoleptic parameters as taste and aroma, which in experimental samples better than in the control one. In particular, a characteristic piquant nutty aroma and taste and longer "mouth-feeling" sensation appear in the experimental samples of candy masses. Further increase in the dosage of the additive - over then $10 \%$ - leads to the appearance of a mealy aftertaste and a harsh flavor of flaxseed. Thus, the effective concentration of protein-fat composite in the candy mass at the level of $10 \%$ was chosen based on the results of sensory evaluation.

The results of the physicochemical quality control parameters of candy masses determining (Table 2) indicate that the change in the moisture mass fraction and the fat mass fraction takes place within the limits of the standardized values with the adding of $10 \%$ of protein-fat composite to the cream candy mass. A slight decrease in the total sugar content does not affect for organoleptic characteristics of candy mass, but reduces the cost of production.

\section{Conclusions}

It is determined that the protein-fat composite based on flax, sesame and sunflower seeds promotes to increase of the oxidative stability of creamy candy masses, and also has a positive effect on their organoleptic parameters such as taste, aroma and "mouth-feeling" sensation. It is determined that the protein-fat composite adding to these candy masses in an amount of $10 \%$ allows keeping the normalized physicochemical quality control parameters within the framework acording to the requirements of the DSTU 4135.

The possibility of using of protein-fat composite based on flax, sesame and sunflower seeds in the production of "truffle" cream candies as an additive increasing the biological value of the product and improving its organoleptic characteristics, and, accordingly, raising the consumer's assessment of the quality of sweets is determined. The developed products can be used in everyday nutrition of athletes, heavy manual workers, military personnel, as well as children and adolescents. It will reduce the deficit of a number of essential amino acids, polyunsaturated fatty acids, antioxidants and, as a result, improve the prevention of diseases caused by unbalanced nutrition: metabolic disorders proteins and lipids, atherosclerosis and premature aging of the body.

\section{References}

[1] Pokotylova, O. I. (2011). Suchasniy stan i modelyuvannya rozvytku tovarnoho asortymentu pidpryyemstv kharchovoyi promyslovosti Ukrayiny. Upravlinnya proektamy ta rozvytok vyrobnytstva, 4 (40), 70-74.

[2] Aidoo, R. P., Depypere, F., Afoakwa, E. O., Dewettinck, K. (2013). Industrial manufacture of sugar-free chocolates - applicability of alternative sweeteners and carbohydrate polymers as raw materials in product development. Trends in Food Science \& Technology, 32 (2), 84-96. doi: 10.1016/ j.tifs.2013.05.008

[3] Bartosz, G. (2013). Food Oxidants and Antioxidants: Chemical, Biological, and Functional Properties. CRC Press, Taylor \& Francis Group, 568.

[4] Talbot, G. (2015). Specialty Oils and Fats in Food and Nutrition: Properties, Processing and Application. Cambridge, Elsevier Science \& Technology, 384.

[5] Karnaushenko, L. I., Iorhachova, K. H., Kaluhyna, I. M.; assignee: Odessa State Academy of Food Technologies (31.10.1997). Sposib vyrobnytstva pralinovykh tsukerok. Patent of Ukraine No. 17928, 
MPK A23G3/48, A23G3/34. Filed 06.03.1997. Available at: http://uapatents.com/5-17928-sposib-virobnictva-pralinovikh-cukerok.html

[6] Eliseeva, L, Yurina, O., Hovhannisyan, N. (2016). Nuts as raw material for confectionary industry. Annals of Agrarian Sciences. 15 (1), 71-74. doi: 10.1016/j.aasci.2017.02.007

[7] Ananieva, V., Krichkovska, L., Belinska, A., Dubonosov, V., Petrov, S. (2016). Research of dry plant concentrates - ingredient of a food health improvement. EUREKA: Physics and Engineering, 4 (5), 17-25. doi: 10.21303/2461-4262.2016.000124

[8] Yanytskyi, V. V., Obolnina, V. A. (1999). Roslynni dobavky v kondyterskykh vyrobakh. Kharchova ta pererobna promyslovist, $9,14$.

[9] Gramza-Michałowska, A., Kobus-Cisowska, J., Kmiecik, D., Korczak, J., Helak, B., Dziedzic, K., Górecka, D. (2016). Antioxidative potential, nutritional value and sensory profiles of confectionery fortified with green and yellow tea leaves (Camellia sinensis). Food Chemistry, 211, 448-454. doi: 10.1016/ j.foodchem.2016.05.048

[10] Bochkarev, S., Papchenko, V., Matveeva, T., Belinska, A., Rudniev, V. (2016). Development of the protein-fatty base of the sugar confectionery for nutrition of the sportsmen. Technology Audit and Production Reserves, 5 (3 (31)), 58-64. doi: 10.15587/2312-8372.2016.81142

[11] Bochkarev, S., Matveeva, T., Krichkovska, L., Petrova, I., Petrov, S., Belinska, A. (2017). Research of the oilseeds ratio on the oxidative stability of the protein-fat base for sportsmen. Technology Audit and Production Reserves, 2 (3 (34)), 8-12. doi: 10.15587/2312-8372.2017.96665

[12] Bochkarev, S., Krichkovska, L., Petrova, I., Petrov, S., Varankina, O., Belinska, A. (2017). Research of influence of technological processing parameters of protein-fat base for supply of sportsmen on activity of protease inhibitors. Technology Audit and Production Reserves, 4 (3 (36)), 27-30. doi: 10.15587/23128372.2017.108376 